\title{
First record of Lichtenstein's Sandgrouse Pterocles lichtensteinii in Lebanon, 2020
}

\author{
Michel SAWAN
}

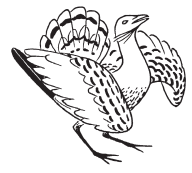

Received: June 18, 2020 - Revised: August 17, 2020 - Accepted: August 31, 2020

Sawan, M. 2020. First record of Lichtenstein's Sandgrouse Pterocles lichtensteinii in Lebanon, 2020. - Ornis Hungarica 28(2): 212-214. DOI: 10.2478/orhu-2020-0026

\begin{abstract}
The Lichtenstein's Sandgrouse (Pterocles lichtensteinii) is a nomadic, mostly nocturnal species. Its world range includes several countries in Africa, as far south as Kenya, and Asia as far east as Pakistan, but within the Middle East, it is a resident in Egypt, Southern Israel and Jordan, Saudi Arabia, Yemen, Oman and Southern Iran. Like other members of its family, it is found in very dry habitats including wadis and stony deserts. Seeing a flock of them in Lebanon is extraordinary. They were sighted for the first time in the country. The dry hot wind in that time of the year might have brought them there. A poacher shot the flock and killed six birds during night hunting.
\end{abstract}

Keywords: Liechtenstein's Sandgrouse, first record, new species in Lebanon, night poaching, Pterocles lichtensteinii

Összefoglalás A csíkos pusztaityúk (Pterocles lichtensteinii) egy nomadizáló, éjszakai életmódot folytató faj. Elterjedési területe Afrikában Kenyáig, Ázsiában a Közel-Keletig, Pakisztánig terjed. Állandó faj Egyiptomban, Izrael déli részén, Jordániában, Szaúd-Arábiában, Jemenben, Ománban és Irán déli részén. A rokon fajokhoz hasonlóan száraz élőhelyeken, vádikban, köves sivatagokban fordul elő. Libanoni előfordulása ismert elterjedési területén kívülre esik. Ez az első ismert megkerülése, amiben valószínüleg szerepet játszott az ebben az időszakban fújó meleg, száraz szél. Egy orvvadász belelőtt a csapatba és megölt 6 példányt egy éjszakai vadászat során.

Kulcsszavak: szudáni pusztaityúk, Pterocles lichtensteinii, első előfordulás, új faj Libanonban, orvvadászat

e-mail:michelsawan@hotmail.com

Lichtenstein's Sandgrouse (Pterocles lichtensteinii) is a nomadic, mostly nocturnal species, reaching $25 \mathrm{~cm}$ in length, in the family Pteroclidae. Its world range includes several countries in Africa, from Morocco through the Sahara to Chad (P. l. targius) and from South Sudan as far south as Central Kenya (P. l. sukensis), and Asia as far east as Iran and Pakistan (P. l. arabicus), but within the Middle East (P. l. lichtensteinii), it is a resident in Egypt, Southern Israel and Jordan, Saudi Arabia, Yemen (P. l. ingramsi, only resident in EC Yemen), and Oman (BirdLife International 2016, de Juana \& Kirwan 2020).

Like other members of its family it is found in very dry habitats including wadis and stony deserts. Their nocturnal nature and their habit of drinking before dawn and after dusk means that they are often very hard to spot. The five geographical races are currently classed as being of Least Concern by Birdlife International (2016). The closest subspecies to Lebanon (P. l. lichtensteinii) normally occurs in Southern Israel and, prior to the events described below, this species had never been recorded from Lebanon.

At 11 p.m. on the $19^{\text {th }}$ of January 2020, I was called by a young man (a hunter) who had been hunting Song Thrushes (Turdus philomelos) at night when he saw a very fast-flying 
flock of about 12 birds. He fired at the flock landed on the ground and killed three birds and caught another three alive.

I identified the birds as a nominate subspecies of the Liechtenstein's Sandgrouse (P. l. lichtensteinii), that is endemic from Israel to Somalia and Socotra. It was the first observation of this species in Lebanon. I used the Collins Field Guide (Svensson et al. 1999) to confirm the identification of the species because the area where these birds were shot is a passage of the Black-Bellied Sandgrouse (Pterocles orientalis) too, since the poacher showed me photos of one that was killed earlier a couple of months ago. The location they were shot was in Bqaiaa, Aakkar District, North Lebanon.

The resulting photo (Figure 1) shows one male (in the middle) and two females (on each side). Liechtenstein's Sandgrouse has never been recorded in Lebanon before, therefore, this is the first record. On examining the birds, it was obvious that they had been shot with shotgun pellets. The male

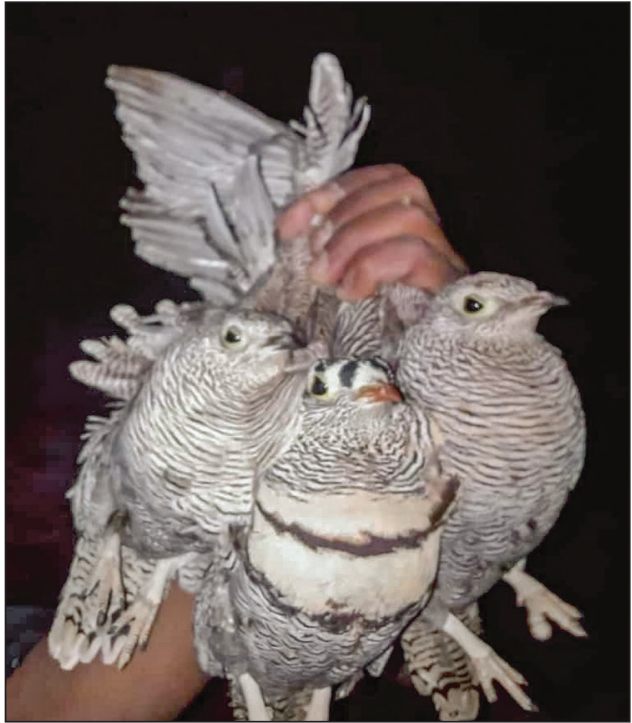

Figure 1. Lichtenstein's Sandgrouse (Pterocles lichtensteinii) caught by a poacher in Akkar, Lebanon at $11 \mathrm{pm}$ on the $19^{\text {th }}$ of January 2020, photo: Michel Sawan

1.ábra Csíkos pusztaityúkok Libanonban, Akkar közelében 2020. január 19-én, este 11 órakor orvvadász által fogva, illetve lőve (fotó: Michel Sawan) shown in Figure 1. had obviously been hit in the chest by many pellets (the damage is just visible in the photo) and one of the females had a paralysed leg due to a pellet in the femur.

This species is resident throughout its entire distribution. Although it is nomadic the nearest known populations being over 550-600 km away in Southern Israel, and the nearest known recorded vagrancy being in Iraq (Porter et al. 1996) and as it would be a new addition to the Lebanese bird list, it is important to exclude the possibility that these birds were smuggled into the country, or had arrived here by some reasons other than a natural one.

The hunter often shows me his prey and consults me when he shoots a new species or encounters a species he has not seen before. He has shown me many of his prey, including Black-bellied (Pterocles orientalis) and Pin-tailed Sandgrouse (P. alchata) that I have reported previously. However, since he made me promise not to reveal his name or his true identity, none of these photos can be posted.

It is highly unlikely that these birds were smuggled, either by the hunter or by anybody else because of his poor financial background. The fact that the birds had obviously been shot, and that three were already dead before I saw them also rules out any possibility of their origin as smuggled birds. The origin of these birds obviously cannot be established with any certainty but given the nomadic nature of the species, it is possible that they might have come from the nearest known populations in Southern Israel and Jordan. However, it 
is possible that other populations close to the location of this sighting remain yet to be discovered.

This species likes desert or semi-desert habitat, but although many areas of suitable habitat can be found very close to the location of this sighting, both in Northern Lebanon and in Syria (the Syrian border is less than $60 \mathrm{~km}$ away). These have been inaccessible to most people for several years due to security reasons and even before that were very little visited, so it is possible that small breeding populations exist in either or both of these countries. Also, because of the nocturnal habits of Lichtenstein's Sandgrouse, and the relatively small number of knowledgeable birdwatchers in Lebanon and Syria, particularly in the areas where it might occur, it would not be very surprising for a small population being unnoticed, particularly if it was more recently established.

It was never ranked as a gamebird here because it did not exist on the bird lists in Lebanon. Like many birds that are shot during night hunting, they did not have a chance to stay and breed maybe in the next few months. This will open the doors for further studies to confirm the possible breeding of the species in Lebanon. Night poaching and illegal hunting are common and are threats to many non-gamebirds during the migration seasons.

\section{Acknowledgements}

I would like to thank Mr. Colin Conroy for reviewing and helping editing the article. And I want to thank Dr. Ghassan Jaradi and Mr. Martin Kaech for the confirmation of my identification for the birds.

\section{References}

de Juana, E. \& Kirwan, G. M. 2020. Lichtenstein's Sandgrouse (Pterocles lichtensteinii). Version 1.0. - In: del Hoyo, J., Elliott, A., Sargatal, J., Christie, D. A. \& de Juana, E. (eds.) Birds of the World. - Cornell Lab of Ornithology, Ithaca, NY, USA, DOI: 10.2173/bow.licsan1.01

BirdLife International 2016. Pterocles lichtensteinii. - In: IUCN Red List of Threatened Species: e. T22693028A93379543. - DOI: 10.2305/IUCN.UK.2016-3.RLTS.T22693028A93379543.en

Porter, R. F., Christiansen, S. \& Schiermacker-Hansen, P. 1996. Field Guide to the Birds of the Middle East. Poyser, London

Svensson, L., Mullarney, K., Zetterstroöm, D. \& Grant, P. 2009. Collins Bird Guide. $2^{\text {nd }}$ ed. - Harper Collins, London

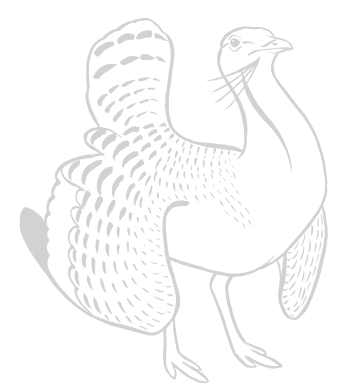

